\title{
Pengembangan Mikrogranul Mukoadhesif Ekstrak Kayu Manis Dengan Kombinasi Polimer Karbopol Dan Gelatin
}

\author{
Sri Wardatun ${ }^{*}$, Erni Rustiani ${ }^{2}$, Opi Damahyanti ${ }^{3}$ \\ ${ }^{1,2,3}$ Program Study of Pharmacy, Pakuan University, Bogor, 16143, Indonesia
}

\begin{tabular}{l}
\hline \hline \multicolumn{1}{c}{ Article info } \\
History \\
Submission: $02-04-2019$ \\
Review: 23-12-2019 \\
Accepted: $22-02-2020$ \\
*Email: \\
sri.wardatun@unpak.ac.id
\end{tabular}

DOI: $10.33096 /$ jffi.v7i1.477

Keywords:

mikrogranul mukoadhesif; ekstrak kayu manis; karbopol 934B; gelatin tipe B

\begin{abstract}
Senyawa bahan alam umumnya memiliki kelarutan yang rendah dan absorpsi yang lemah dalam tubuh. Pengembangan formula mikrogranul mukoadhesif dari ekstrak kayu manis dengan polimer karbopol dan gelatin bertujuan untuk meningkatkan kelarutan dan absorpsi ekstrak kayu manis dalam tubuh. Pada penelitian ini, mikrogranul mukoadhesif diformulasikan menggunakan ekstrak kayu manis dengan tiga formulasi yang berbeda yaitu penggunaan karbopol 934 P 5\%: gelatin tipe B 4\% (F1), karbopol 934P 5\%: gelatin tipe B 5\% (F2) dan karbopol $9345 \%$ : gelatin tipe B 6\% (F3). Hasil penelitian menunjukkan bahwa kombinasi karbopol 934P 5\%: gelatin tipe B 5\% (F2) merupakan formulasi mikrogranul mukoadhesifyang menghasilkan kadar asam sinamat paling tinggi setelah uji wash off menggunakan jaringan lambung (6,48\%) dan usus tikus (55,21\%). Hasil evaluasi fisik terhadap mikrogranul meliputi uji sudut diam, kadar air, laju alir granul, uji wash off, morfologi dan ukuran partikel menunjukkan bahwa mikrogranul mukoadhesif dari F2 menghasilkan kualitas granul paling baik.
\end{abstract}

\section{Pendahuluan}

Kayu manis (Cinnamomum burmanii Blume) adalah salah satu tanaman obat tradisional yang sering digunakan untuk berbagai keperluan kesehatan. Senyawa trans-cinnamaldehyde merupakan komponen utama minyak kayu manis dan bertanggung jawab atas aroma khasnya (Zinn et al., 2015). Senyawa aktif lain yang ditemukan dalam kayu manis adalah asam sinamat dan merupakan senyawa penanda ekstrak kayu manis karena senyawa tersebut secara khusus ditemukan pada pohon kayu manis. Secara alami, asam sinamat bertindak sebagai enzim penghambat PTP1B (protein tirosin fosfatase 1B) dan terbukti sebagai agen pelepas insulin yang efektif (Sharma, 2011). Senyawa pada kayu manis dapat mengaktifkan sel $\beta$ dalam pankreas untuk menghasilkan insulin dan melepaskannya untuk menormalkan kadar insulin dalam sirkulasi darah (Allen et al., 2013; Cao et al., 2007.

Penelitian lain menyebutkan bahwa ekstrak kayu manis dapat menurunkan kadar glukosa darah puasa tikus model diabetes (Rahimah et al., 2011)

Meskipun banyak keuntungan yang diperoleh dari produk alami, di lain pihak, ekstrak bahan-bahan alami umumnya memiliki kelarutan yang rendah dalam lemak dan bioavailabilitas yang rendah dalam tubuh. Penelitian sebelumnya menunjukkan bahwa ekstrak tanaman dalam bentuk mikrogranul mukoadhesif memiliki potensi adhesi yang lebih tinggi untuk membran mukosa yang mengarah pada peningkatan konsentrasi senyawa obat di sisi aktif (Kharenko et al., 2009). Peningkatan konsentrasi senyawa obat pada sisi aktif menjadi topik utama penelitian ini.

Polimer telah memainkan peran yang tak terpisahkan dalam pembuatan produk farmasi. Penggunaan polimer hidrofilik dapat meningkatkan waktu penahanan obat pada jaringan mukosa, dan dapat mengarah ke pelepasan bertahap oleh pasien (Kharenko et al., 2009). Karbopol adalah salah satu polimer mukoadhesif yang paling umum digunakan. Penggunaan polimer karbopol dan gelatin sebagai agen mukoadhesif sangat dianjurkan karena sifat bioadhesif yang kuat (Drug Development \& Delivery, 2008, Mansuri et al., 2016). Kombinasi polimer karbopol dan gelatin dalam formulasi sediaan mukoadhesif terbukti menghasilkan mikrogranul berkualitas tinggi (Indrawati et al., 2005). Kombinasi yang tepat dari konsentrasi karbopol dan gelatin diperlukan untuk menghasilkan mukoadhesif dengan kekuatan optimal (Mansuri et al., 2016). Penelitian sebelumnya menunjukkan bahwa kombinasi 1 bagian karbopol dengan 1 bagian gelatin polimer adalah formula terbaik untuk menghasilkan granul mukoadhesif nifedipin dengan kualitas baik (Widayanti et al., 2011). Penelitian ini akan mengembangkan formula mikrogranul mukoadhesif dari ekstrak kulit kayu manis dengan kombinasi polimer karbopol dan gelatin untuk memperoleh mikrogranul mukoadhesif dengan kualitas paling baik. 


\section{Bahan Dan Metode \\ II.1 Bahan dan Alat}

Bahan-bahan yang digunakan dalam penelitian ini adalah kulit kayu manis (Cinnamomum burmanii Blume) yang diperoleh dari Pasar Induk Kemang Bogor serta dideterminasi di Lembaga Ilmu Pengetahuan Indonesia (LIPI), Cibinong Bogor. PVP-K30, Karbopol 934P, gelatin, avicel PH 102, akuades, potongan mukosa lambung dan usus tikus putih segar, medium cairan lambung dan usus buatan, asam sinamat standar, etanol $96 \%$, lem sianoakrilat, para film, natrium klorida $\mathrm{P}$, asam klorida $\mathrm{P}$, natrium hidroksida $0,2 \mathrm{~N}$, kalium 10kstrak10 fosfat.

Alat-alat yang digunakan dalam penelitian ini antara lain: neraca analitik, oven, grinder, tanur (Vulcan A-55 ${ }^{\circledR}$, Moisture Balance (AND MX-50 ${ }^{\circledR}$ ), Vacuum Dryer, Silent Crusher (Heidolph ${ }^{\circledR}$ ), mikroskop 10kstrak10, mikroskop 10kstrak1010r (Anti-Mould $^{\circledR}$ ), Spektrofotometer UV-VIS, Disintegrator Tester (LIJ-1 $\left.{ }^{\circledR}\right)$, dan alat-alat gelas lainnya.

\section{II.2 Pembuatan Ekstrak kayu manis}

Kulit kayu manis kgdibersihkan dari kotoran yang menempel, kemudian dicuci bersih dibawah air mengalir dan dikeringkan dalam oven dengan suhu $40^{\circ} \mathrm{C}$ selama \pm 3 hari. Setelah kering dibersihkan kembali dari kotoran yang masih menempel.Kemudian digiling dan diayak menggunakan pengayak mesh 40 (DepKes RI, 1985).

Serbuk kering simplisia kulit kayu manis dimaserasi menggunakan 10 bagian pelarut etanol $96 \%$. Serbuk kayu manis direndam selama 6 jam pertama 10kstra sekali-sekali diaduk, kemudian didiamkan selama 18 jam. Maserat dipisahkan dengan cara pengendapan. Proses penyarian diulangi sekurang kurangnya dua kali dengan jenis dan jumlah pelarut yang sama. Semua maserat yang dikumpulkan kemudian dikeringkan dengan vaccum dryer hingga diperoleh 10kstrak kering.

\section{II.3 Penentuan Kadar Asam Trans-Sinamat dari Ekstrak}

Modifikasi sebanyak $100 \mathrm{mg}$ 10kstrak dimasukkan dalam labu ukur lalu tambahkan etanol sampai $10 \mathrm{~mL}$, kemudian dimasukkan kedalam gelas kimia dan diaduk dengan alat pengaduk elektrik pada suhu $25^{\circ} \mathrm{C}$ selama 15 menit, setelah itu larutan diambil $1 \mathrm{~mL}$ dimasukkan ke dalam labu 10 mLditambahkan etanol sampai batas (pengenceran pertama). Larutan diambil $1 \mathrm{~mL}$ dimasukkan ke dalam labu $10 \mathrm{~mL}$ ditambahkan etanol sampai batas (pengenceran kedua).Larutan diambil $5 \mathrm{~mL}$ dimasukkan ke dalam labu $10 \mathrm{~mL}$ ditambahkan etanol sampai batas (pengenceran ketiga) Lalu larutan diukur serapannya pada 10kstrak gelombang maksimum (Vy Thuy Truong, 2007).

\section{II.4 Formulasi Mikrogranul Mukoadhesif dengan Polimer Karbopol dan Gelatin}

Ekstrak kering kulit kayu manis dibuat massa 10kstrak10 campuran karbopol 934P, gelatin dan avicel PH 102 dengan penambahan aquadest hingga membentuk masa yang kompak, kemudian dihomogenkan dengan silent crusher (Heidolph ${ }^{\circledR}$ ) dengan kecepatan 20-35 RPM dan waktu selama 15 menit. Massa dikeringkan dalam oven dengan suhu $35^{\circ} \mathrm{C} \pm 0,5^{\circ} \mathrm{C}$ selama 1 hari, setelah kering diayak dengan mesh 100 . Setelah selesai dilakukan evaluasi terhadap mikrogranul mukoadhesif (Ikasari, dkk., 2015). Formula mikrogranul mukoadhesif dapat dilihat pada Tabel 1 .

Tabel 1. Formula Mikrogranul Mukoadhesif dengan Polimer Karbopol dan Gelatin

\begin{tabular}{lccc}
\hline \multicolumn{1}{c}{ Bahan } & Formula 1 (\%) & Fomula 2 (\%) & Formula 3 (\%) \\
\hline Ekstrak kulit kayu manis & 59 & 59 & 59 \\
Karbopol 934P & 5 & 5 & 5 \\
Gelatin type B & 4 & 5 & 6 \\
Avicel PH 102 ditambahkan hingga & 100 & 100 & 100 \\
\hline
\end{tabular}

(Widayanti, dkk, 2011)

\section{II.5 Evaluasi Granul}

Evaluasi granul meliputi uji kadar air, uji sudut istirahat, uji aliran, uji wash off, uji morfologi dan ukuran partikel. Senyawa penanda dalam 10kstrak kayu manis adalah asam sinamat sehingga keberadaan senyawa ini dari sediaan ditentukan.

\section{Uji Kadar Air}

Penentuan kadar air mikrogranul mukoadhesif dilakukan dengan menggunakan moisture balance.

\section{Uji Sudut Istirahat}

Pengujian sudut istirahat dilakukan dengan memasukkan sejumlah massa granul ke dalam corong. Massa yang jatuh akan membentuk kerucut, lalu diukur tinggi dan diameter kerucut.

\section{Uji Aliran}

Uji aliran dilakukan dengan cara sebanyak $100 \mathrm{~g}$ granul dilewatkan ke dalam alat granule flow tester sampai massa melewati corong, kemudian dicatat waktunya. Pengukuran dilakukan sebanyak 3 kali. Penghitungan daya aliran dilakukan menggunakan rumus: $f=\frac{M}{T}$

Keterangan: $\mathrm{f}=$ Daya aliran $($ gram/detik $), \mathrm{T}=$ Waktu (detik), $\mathrm{M}=$ Massa Granul (gram) 


\section{Uji Kadar Asam Sinamat}

Uji kadar asam sinamat dimulai dengan menetapkan panjang gelombang maksimum asam sinamat menggunakan Spektrofotometer UV-Vis. Selanjutnya menimbang mikrogranul sebanyak 100 mg dimasukkan dalam labu ukur $10 \mathrm{~mL}$ kemudian diencerkan dengan etanol pa sampai tanda batas, kemudian dimasukkan ke dalam gelas kimia dan diaduk dengan alat pengaduk elektrik pada suhu $25^{\circ} \mathrm{C}$ selama 15 menit. Larutan diambil $1 \mathrm{~mL}$ dimasukkan dalam labu $10 \mathrm{~mL}$ kemudian diencerkan dengan etanol pa sampai tanda batas (pengenceran pertama). Larutan diambil $1 \mathrm{~mL}$ dimasukkan dalam labu $10 \mathrm{~mL}$ kemudia diencerkan dengan etanol pa sampai tanda batas (pengenceran kedua). Lalu diukur serapannya pada panjang gelombang maksimum.

\section{Uji Wash off}

Pembuatan cairan lambung buatan tanpa enzim

$\mathrm{NaCl} \mathrm{P}$ sebanyak 2,0 gram dilarutkan dalam 7,0 $\mathrm{ml} \mathrm{HCl} \mathrm{P}$. Kemudian cairan ini diendapkan dengan air suling hingga 1 liter dan diperiksa pada $\mathrm{pH}$ 1,2 \pm 0,1 (Suryani, 2009).

Pembuatan cairan usus buatan tanpa enzim

Kalium hidrogen fosfat sebanyak 6,8 gram dicampurkan dalam $250 \mathrm{~mL}$ air suling dengan 190 $\mathrm{mL} \mathrm{NaOH} \mathrm{0,2} \mathrm{N} \mathrm{yang} \mathrm{telah} \mathrm{diencerkan} \mathrm{hingga} 400$ $\mathrm{mL}$. Selanjutnya, $\mathrm{pH}$ campuran diatur hingga 7,5 \pm 0,1 dengan penambahan $\mathrm{NaOH} \quad 0,2 \mathrm{~N}$ dan digenapkan dengan air suling hingga 1 liter (Suryani, 2009).

\section{Penyiapan membran mukosa lambung dan usus}

Penyiapan mumbran mukosa dilakukan melalui tahapan berikut : a) Tikus yang dipilih adalah tikus yang sehat dengan bobot $250 \mathrm{~g}$. Sehari sebelumnya tikus dipuasakan terlebih dahulu, b) Tikus dimatikan dengan kloroform atau eter, c) Pembedahan dilakukan pada bagian abdomal, kemudian organ lambung dan usus diambil, d) Jaringan dicuci dengan $\mathrm{NaCl}$ fisiologis dan kemudian direndam dengan cairan lambung dan usus buatan (Suryani, 2009).

Cara kerja uji Wash Off

Kaca objek disiapkan sebagai media pelekatan potongan jaringan lambung atau usus tikus segar dengan menggunakan lem sianoakrilat dan ujungnya dikunci dengan parafilm, ditempatkan secara merata mikrogranul mukoadhesif sebanyak $100 \mathrm{mg}$ pada mukosa lambung atau usus menggunakan pinset. Kaca objek yang dilekatkan potongan jaringan lambung ditempatkan pada alat uji disintegrasi dan kaca objek yang dilekatkan potongan jaringan usus ditempatkan pada alat uji disintegrasi, digerakan dengan kecepatan 30 kali per menit dalam medium cairan lambung atau cairan usus buatan tanpa enzim pada suhu $37 \pm 0,5^{\circ} \mathrm{C}$ (Indrawati, 2005). Pengujian ini hanya dilakukan sampai 2 jam karena lebih dari 2 jam keutuhan jaringan mukosa tak layak untuk pengujian selanjutnya.

\section{Analisis Kadar Asam Sinamat}

Mikrogranul mukoadhesif yang masih menempel diambil pada mukosa lambung dan usus setelah uji wash off. Penentuan kadar asam sinamat pada mikrogranul mukoadhesif ekstrak kering kulit kayu manis (Cinnamomum burmanii) setelah uji wash offini dilakukan tahapan yang sama seperti penentuan kadar asam sinamat pada mikrogranul mukoadhesif ekstrak kering kulit kayu manis (Cinnamomum burmanii) sebelum uji wash off. Lakukan perbandingan dengan uji analisis kadar asam sinamat sebelum uji wash off.

\section{Hasil Dan Diskusi}

Kulit kayu manis dicuci dan dibersihkan serta dikeringkan lalu digrinder. Rendemen simplisia yang diperoleh yaitu sebesar $85,00 \%$. Karakteristik serbuk simplisia kulit kayu manis yaitu memiliki warna cokelat muda, bau aromatik khas dan rasa sedikit manis dan sedikit pahit.

Hasil pengujian susut pengeringan serbuk simplisia kulit kayu manis rata-rata sebesar 7,940\%. Simplisia kulit kayu manis mengandung senyawa yang mudah menguap yaitu minyak atsiri sehingga parameter pengujian menggunakan prosedur penetapan susut pengeringan (Depkes RI, 1995). Hasil penetapan susut pengeringan simplisia kulit kayu manis memenuhi syarat menurut Depkes RI (2008), yaitu tidak lebih dari $12 \%$. Hasil pengujian kadar abu rata-rata serbuk simplisia kulit kayu manis sebesar 3,04 \%. Menurut Depkes RI (1977), syarat kadar abu serbuk simplisia kulit kayu manis tidak lebih dari 3,5\%. Hal ini menunjukkan bahwa serbuk simplisia kulit kayu manis memenuhi syarat. Pengujian kadar abu serbuk simplisia bertujuan untuk mengetahui tingkat cemaran senyawa non organik dan mineral dalam serbuk simplisia, baik yang berasal dari simplisia kulit kayu manis atau dari proses pembuatan serbuk simplisia.

Pembuatan ekstrak kering kulit kayu manis dalam penelitian ini dengan metode maserasi menggunakan pelarut etanol 96\%. Metode ini dipilih karena menurut penelitian sebelumnya yang dilakukan oleh Wardatun et al (2017), penggunaan pelarut etanol 96\% menghasilkan kadar asam sinamat yang paling tinggi dibandingkan etanol $70 \%$ dan etanol $50 \%$.

Ekstrak kering kulit kayu manis dibuat untuk mempermudah formulasi sehingga ekstrak dapat bercampur rata dengan bahan tambahan yang lain. Ekstrak kering yang dihasilkan berwarna cokelat tua, bau aromatik kuat dan rasa sedikit manis dan sedikit pahit. Rendemen ekstrak kering yang diperoleh 31,21\%. Menurut penelitian sebelumnya yang dilakukan oleh Wardatun et al (2017) diperoleh rendemen ekstrak kering sebesar 20,86\%. Hasil pengujian rata rata kadar air ekstrak kering kulit kayu manis yaitu 4,44\%, hasil ini memenuhi syarat menurut Voight (1995),yaitu kadar air ekstrak kering secara umum kurang dari 5\%. Hasil 
penelitian Wardatun et al (2017) menunjukkan kadar air ekstrak kering kulit kayu manis yaitu 3,890\%.

Mikrogranul ekstrak kayu manis dibuat dengan granulasi basah. Mikrogranul yang dihasilkan memiliki warna cokelat muda dan memiliki bau yang khas. Gambar mikrogranul kombinasi karbopol 934P : gelatin dapat dilihat pada Gambar 1 .

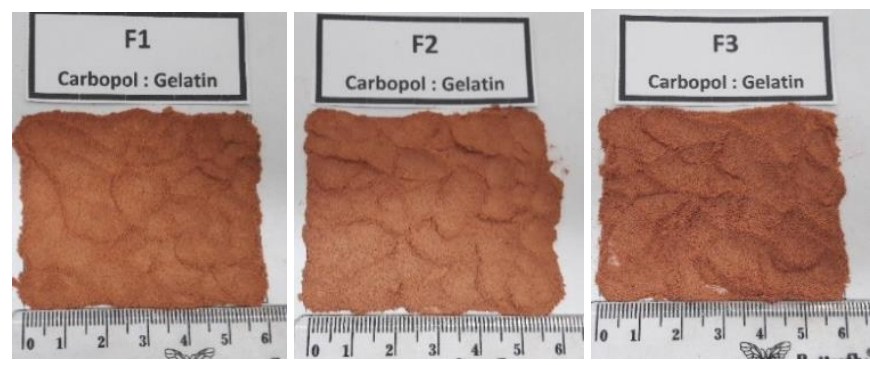

Gambar 1. Mikrogranul mukoadhesif ekstrak kayu manis

Hasil pengujian kadar air, daya alir dan sudut diam mikrogranul kombinasi karbopol 934P : Gelatin dapat dilihat pada Tabel 2.

Tabel 2. Hasil Evaluasi Mikrogranul Kombinasi Karbopol 934P : Gelatin

\begin{tabular}{cccc}
\hline \multirow{2}{*}{ Evaluasi } & \multicolumn{3}{c}{ Formula } \\
\cline { 2 - 4 } & $\mathbf{1}$ & $\mathbf{2}$ & $\mathbf{3}$ \\
\hline Kadar air (\%) & $3,03 \pm 0,10$ & $2,85 \pm 0,11$ & $2,66 \pm 0,04$ \\
& (Memenuhi syarat) & (Memenuhi syarat) & (Memenuhi syarat) \\
Daya alir (g/det) & $0,87 \pm 0,07$ & $0,77 \pm 0,05$ & $0,73 \pm 0,03$ \\
& (Sangat Kohesif) & (Sangat Kohesif) & (Sangat Kohesif) \\
Sudut diam $\left({ }^{\circ} 0\right)$ & $44,83 \pm 4,80$ & $44,20 \pm 2,21$ & $41,80 \pm 2,03$ \\
& (Sukar Mengalir) & (Sukar Mengalir) & (Sukar Mengalir) \\
\hline
\end{tabular}

Hasil penetapan kadar air pada ketiga formula mikrogranul kombinasi karbopol 934P : gelatin memenuhi syarat menurut Hadisoewignyo dan Fudholi (2013) yaitu kelembaban granul idealnya $3-5 \%$. Hasil penelitian menunjukkan bahwa semakin besar konsentrasi gelatin maka kadar air mikrogranul semakin rendah, hal ini dikarenakan gelatin larut dalam air panas dan jika didinginkan akan membentuk gel sehingga menyerap air (Depkes, 1995).

Berdasarkan hasil uji statistik menunjukkan bahwa terdapat perbedaan yang signifikan antar formula terhadap kadar air granul, tetapi tidak terdapat perbedaan signifikan antar formula terhadap daya alir granul, serta tidak terdapat perbedaan signifikan antar formula terhadap sudut diam granul. Hasil evaluasi daya alir mikrogranul yaitu pada ketiga formula termasuk dalam kategori sangat kohesif. Hasil evaluasi sudut diam pada ketiga formula memiliki sifat sukar mengalir. Hal ini disebabkan karena waktu alir granul lambat sehingga sudut diamnya besar. Hasil penelitian menunjukkan variasi konsentrasi gelatin sebagai bahan pengikat yang ditambahkan pada ketiga formula mempengaruhi sudut diam yang dihasilkan. Semakin tinggi konsentrasi gelatin maka sudut diam yang terbentuk akan semakin kecil. Apabila sudut istirahat granul besar atau sama dengan $40^{\circ}$ maka daya mengalirnya kurang baik (Lachman, 1994). Berdasarkan hasil pemindaian bentuk morfologi menggunakan SEM (Scanning Electron Microscope) menunjukkan bahwa granul memiliki bentuk yang tidak bulat sehingga menghambat aliran granul dan waktu alirnya menjadi lebih lama. Waktu alir dipengaruhi oleh jumlah serbuk halus, porositas, kerapatan jenis, dan bentuk granul (Parrot, 1971).

Uji wash off dilakukan bertujuan untuk mengetahui kemampuan mikrogranul melekat pada mukosa lambung dan usus, dengan menghitung jumlah mikrogranul yang masih melekat pada lambung dan usus selama waktu tertentu. Analisis kuantitatif ditentukan dengan kadar asam sinamat yang diperoleh sebelum dan setelah uji wash off. Uji wash off menggunakan potongan lambung dan usus tikus yang berbeda serta cairan lambung buatan tanpa enzim $(\mathrm{pH} \mathrm{1,2)}$ dan cairan usus buatan tanpa enzim ( $\mathrm{pH} 7,5)$. Pembuatan cairan lambung tanpa enzim $\mathrm{pH}$ 1,2 bertujuan untuk menyesuaikan dengan suasana lambung yang bersifat asam dan cairan usus tanpa enzim $\mathrm{pH}$ 7,5 bertujuan untuk menyesuaikan dengan suasana usus yang bersifat basa. Pengujian dilakukan selama 2 jam karena pada mukosa terdapat musin yang akan mengalami pergantian secara alami oleh mukosa kurang lebih 2 jam, sehingga sekuat apapun polimer yang digunakan akan lepas dari permukaan (Agoes, 2008).

Analisis kadar asam sinamat pada sediaan mikrogranul mukoadhesif dilakukan sebelum dan setelah uji wash off. Penentuan kadar sebelum dan setelah uji wash off dilakukan untuk menghasilkan 
kadar asam sinamat yang masih menempel dan untuk mengetahui formula dengan konsentrasi kombinasi polimer terbaik yang dapat digunakan sebagai mukoadhesif.
Hasil Uji Wash off Dalam Media Usus

Hasil uji wash off dalam media usus dapat dilihat di pada Tabel 3.

Tabel 3. Kadar Asam Sinamat Mikrogranul Kombinasi Karbopol 934P : Gelatin Sebelum dan Setelah Uji Wash Off dalam Media Usus

\begin{tabular}{cccc}
\hline Formula & $\begin{array}{c}\text { Kadar sebelum uji } \\
\text { wash off }(\mathbf{m g} / \mathbf{g}) \pm \text { SD } \\
(\mathbf{\%})\end{array}$ & $\begin{array}{c}\text { Kadar setelah uji wash } \\
\text { off }(\mathbf{m g} / \mathbf{g}) \pm \text { SD }(\%)\end{array}$ & $\begin{array}{c}\text { Perbandingan kadar } \\
\text { sebelum dan setelah } \\
\text { uji wash off }(\%)\end{array}$ \\
\hline 1 & $30,85 \pm 2,65$ & $2,44 \pm 10,25$ & 7,90 \\
2 & $24,37 \pm 19,98$ & $13,46 \pm 23,70$ & $\mathbf{5 5 , 2 1}$ \\
3 & $26,55 \pm 12,96$ & $2,66 \pm 29,12$ & 10,01 \\
\hline
\end{tabular}

Hasil perbandingan kadar asam sinamat kombinasi karbopol 934P : gelatin sebelum dan setelah uji wash off dalam media usus menunjukkan formula 2 menunjukkan perbandingan paling besar yaitu 55,21\%. Hal ini karena karbopol merupakan polimer yang dapat membentuk sistem yang memiliki kekentalan dalam air karena karbopol dapat mengembang dengan menyerap air serta dapat membentuk ikatan hidrogen yang efektif sebagai mukoadhesif dengan adanya air (Agoes, 2008). Menurut Suryani, dkk. (2009), semakin tinggi konsentrasi gelatin maka kekuatan gelatin semakin meningkat. Hal ini meningkatkan daya pelekatan rantai polimer terhadap mukosa. Namun, tingkat kekuatan gelatin memiliki batas optimum dimana kekuatan gelatin yang sangat tinggi dapat menyebabkan penetrasi rantai polimer ke dalam mukosa menjadi berkurang dan pelekatannya juga berkurang. Hal ini sesuai dengan hasil perbandingan kadar formula 1 dengan konsentrasi gelatin 4\% yang memiliki perbandingan lebih kecil dari formula 2 dan formula 3 dengan konsentrasi gelatin 5\% yang memiliki perbandingan lebih kecil dari formula 2 .

\section{Hasil Uji Wash Off dalam Media Lambung}

Hasil kadar asam sinamat sebelum dan setelah uji wash off dalam media usus dapat dilihat pada Tabel 4.

Tabel 4. Kadar Asam Sinamat Mikrogranul Kombinasi Karbopol 934P : Gelatin Sebelum dan Setelah Uji Wash Off dalam Media Lambung

\begin{tabular}{cccc}
\hline Formula & $\begin{array}{c}\text { Kadar sebelum uji } \\
\text { wash } \text { off } \mathbf{( m g / g )} \pm \mathbf{S D} \\
(\mathbf{\%})\end{array}$ & $\begin{array}{c}\text { Kadar setelah uji } \\
\text { wash } \text { off }(\mathbf{m g} / \mathbf{g}) \pm \mathbf{S D} \\
\mathbf{( \% )}\end{array}$ & $\begin{array}{c}\text { Perbandingan kadar } \\
\text { sebelum dan setelah } \\
\text { uji } \text { wash } \text { off }(\mathbf{\%})\end{array}$ \\
\hline 1 & $30,85 \pm 2,65$ & $1,55 \pm 23,87$ & 5,02 \\
2 & $24,37 \pm 19,98$ & $1,58 \pm 8,23$ & 6,48 \\
3 & $26,55 \pm 12,96$ & $1,27 \pm 10,24$ & 4,78 \\
\hline
\end{tabular}

Berdasarkan Tabel 4. perbedaan kadar asam sinamat sebelum dan setelah uji wash off dalam media lambung menunjukkan formula 2 menunjukkan perbandingan paling besar yaitu 6,48\%. Hasil penelitian Widayanti, dkk., (2011), formula granul mukoadhesif nifedipine yang paling baik adalah formula dengan kombinasi polimer karbopol dan gelatin $(1: 1)$. Namun, apabila dilihat dari sifat ekstrak kulit kayu manis yang memiliki $\mathrm{pH}$ basa penyerapannya lebih baik pada media usus dibandingkan media lambung sehingga perbandingan kadar asam sinamat lebih tinggi pada media usus.

Hasil penetapan kadar asam sinamat setelah uji wash off pada mukosa usus lebih tinggi dbandingkan pada mukosa lambung. Hal ini karena adanya interaksi yang kuat pada mukosa usus dengan karbopol dan gelatin yang mampu mengikat musin sehingga terbentuk ikatan kimia yang menghasilkan daya mukoadhesif yang baik. Hal ini juga dikarenakan ekstrak kulit kayu manis yang memiliki $\mathrm{pH}$ yang bersifat basa. Menurut penelitian yang telah dilakukan oleh Hastuti (2014), penambahan kayu manis meningkatkan $\mathrm{pH}$ pada minuman fungsional secang dan daun stevia. Kayu manis merupakan golongan alkali dengan nilai $\mathrm{pH}$ 8,5 . Semakin banyak penambahan kayu manis, $\mathrm{pH}$ minuman yang dihasilkan semakin tinggi. Sehingga dari hasil penelitian ini mikrogranul yang menempel pada mukosa usus lebih banyak dibandingkan pada mukosa lambung. Mikrogranul yang mengandung ekstrak kulit kayu manis berada dalam bentuk tak terionkan sehingga absorpsinya lebih efektif dan banyak pada usus.

\footnotetext{
Hasil Pemindaian Morfologi dan Ukuran Partikel Mikrogranul Mukoadhesif

Pemindaian morfologi dan ukuran partikel mikrogranul mukoadhesif dilakukan terhadap formula terbaik dari hasil pengujian kadar yang paling tinggi setelah uji wash off yaitu formula 2
} 
kombinasi karbopol 934P : gelatin. Pemindaian dilakukan menggunakan metode SEM (Scanning Electron Microscope). Hasil pemindaian diperoleh bentuk morfologi berupa amorf dan tidak terbentuk partikel yang bulat serta terdapat lubang. Hasil pengukuran mikrogranul pada perbesaran 500 kali

diperoleh $17,87-48,77 \mu \mathrm{m}$. Ukuran yang didapat dari hasil pemindaian sesuai dengan persyaratan granul yang diukur dalam satuan mikron yaitu berkisar 38-850 $\mu \mathrm{m}$ Syamsuni, 2006). Gambar hasil pemindaian mikrogranul dapat dilihat pada Gambar 2.

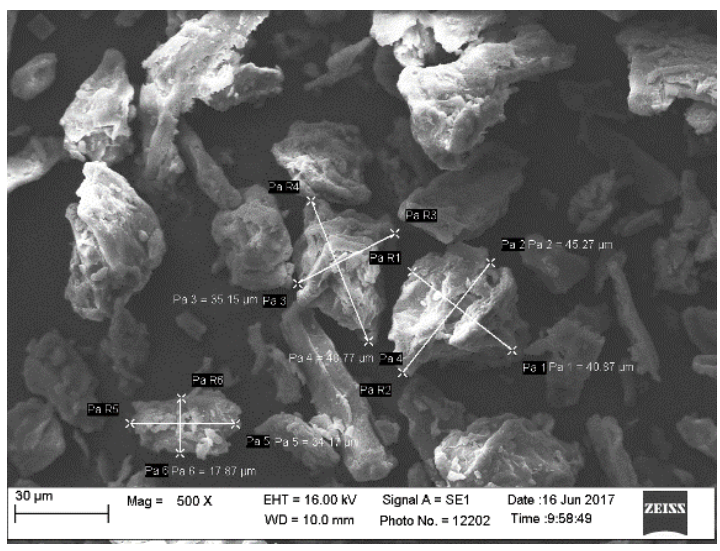

Gambar 2. Ukuran Partikel Mikrogranul Mukoadhesif Kayu Manis

\section{Kesimpulan}

Mikrogranul mukoadhesif ekstrak kulit kayu manis formula 2 dengan kombinasi polimer karbopol 934P 5\% dan gelatin 5\% menghasilkan sediaan dengan kualiatas paling baik.

\section{Daftar Pustaka}

Allen RW, Schwartzman E, Baker WL, Coleman CI, and Phung OJ. 2013. Cinnamon use in type 2 diabetes: an updated systematic review and meta-analysis. Annals of Family Medicine. 11(5): 452-459.

Aulton ME. 1988. Pharmaceutics: The Science of Dosage Form Design. New York: Churchill Livingstone Inc. 247-248

Cao H, Polansky MM, Anderson RA. 2007. Cinnamon extract and polyphenols affect the expression of tristetraprolin, insulin receptor, and glucose transporter 4 in mouse 3T3-L1 adipocytes. Archives of Biochemistry and Biophysics. 459:214-22.

DepKes. 1977. Materia Medika Indonesia. Edisi I. Direktorat Pengawasan Obat dan Makanan. Jakarta. 46.

DepKes RI. 1985.Cara Pembuatan Simplisia. Direktorat Pengawasan Obat dan Makanan. Jakarta. 1-22, 105-127.

DepKes RI. 1995. Farmakope Indonesia. Edisi IV. Direktorat Pengawasan Obat dan Makanan. Departemen Kesehatan Republik Indonesia. Jakarta.1033, 1043.

Drug Development \& Delivery. 2008. Available at http://drug-dev.com/Main/BackIssues/Carbopol174-Polymers-forPharmaceutical-Drug-Deliv-345.aspx. [Accessed 10 August 2017]

Hadisoewignyo L and Fudholi A. 2013. Sediaan Solid. Jakarta: Pustaka Pelajar. 19.
Hastuti, A, M., dan Rustanti, N. 2014. Pengaruh Penambahan Kayu Manis terhadap Aktivitas Antioksidan dan Kadar Gula Total Minuman Fungsional Secang dan Daun Stevia sebagai Alternatif Minuman bagi Penderita Diabetes Mellitus. Journal of Nutrition College. Vol. 3(3). 362-369.

Ikasari ED, Utomo AB, Hanny S, Salasa AT. 2015. The effect of aloe vera powder (Aloe vera (L.) Webb) on physical properties of mucoadhesive microgranules containing ranitidine hydrochloride. World Journal of Pharmaceutical and Life Sciences. 1(I): 224-234.

Indrawati T, Agoes G, Yulinah E, Cahyati E. 2005. Uji daya lekat mukoadhesif secara in vitro beberapa eksipien polimer tunggal dan kombinasinya pada lambung dan usus tikus. Jurnal Matematika dan Sains.10(2): 45-51.

Kharenko EA, Lavionova NI, Demina NB. Muchoadhesive drug delivery system (Review). 2009. Pharmaceutical Chemistry Journal. 43(4):200-208.

Lachman L, Lieberman HA, Kanig JL. 1994. The Teory and Practice Industrial Pharmacy $3^{\text {rd }}$ ed. Translated by Siti Suyatmi. Vol. 1 . Jakarta: UI Press. 1355.

Mansuri S, Kesharwani P, Jain K, Tekade RK, Jain NH. 2016. Mucoadhesion: a promising approach in drug delivery system. Reactive and Funcional Polymer. 100: 151-172

Parrot, LE. 1971. Pharmaceutical Technology Fundamental Pharmaceutics. USA: Burgess Publishing. 76-82.

Prasad BSR, Gupta VRM, Devanna N,Jayasurya K. 2014. Micropheres as drug delivery system-a review. Journal of Global Trends 
in Pharmaceutical Sciences. 5(3):19611972

Rahimah SB, Trusda Siti AD, Abdullah. 2011. Hypoglicemia effect of Cinnamomum burmanii infusion in fasting blood glucose decrement in alloxan induced mice. Jurnal Medika Planta. 1(3).

Rowe RC, Sheskey PJ, Quinn ME. 2009. Handbook of pharmaceutical excipient sixth edition. Chicago: Pharmaceutical Press.

Sharma P. 2011. Cinnamic acid derivatives: a new chapter of various pharmacological activities. Journal of Chemical and Pharmaceutical Research. (2):403-42

Suryani N, Farida S, Astri F. 2000. Kekuatan gel gelatin tipe $\mathrm{B}$ dalam formulasi granul terhadap kemampuan mukoadhesif. Makara Kesehatan. 13(1): 1-4.

Syamsuni, H.A. 2006. Ilmu Resep. Penerbit Buku Kedokteran EGC. Jakarta. 44.

Wardatun S, Rustiani E, Alfiani N, Rissani D. 2017. Study effect type of extraction method and type of solvent to cinnamaldehyde and trans- cinnamic acid dry extract cinnamon (Cinnamomum burmanii (Nees \& T, Nees) Blume. Journal of Young Pharmacists. 9(2):23-25.

Widayanti A, Auzal H, Muslim S. 2011. Formulasi mukoadhesif nifedipin menggunakan kombinasi polimer carbopol 934 dan gelatin type B. Farmasains. 1(3).

Zinn S, Betz T, Medcraft C, Schnell M. 2015. Structure determination on trans cinnamaldehyde by broadband microwave spectroscopy. Physical Chemistry Chemical Physics. 17:16080-16085 